\title{
ANALISIS FAKTOR YANG BERPENGARUH TAERHADAP KETEPATAN TRANSFUSI PADA ANAK DENGAN THALASEMIA $\beta$ MAYOR DI RSU TANGERANG
}

\begin{abstract}
*Ema Hikmah
Abstrak

Komplikasi pada anak dengan thalassemia Beta Mayor dapat terjadi karena ketidaktepatan dalam melakukan transfusi. Ketepatan dalam melakukan transfusi dapat dipengaruhi oleh berbagai macam factor diantaranya adalah usia, jenis kelamin, pendidikan orangtua, pendapatan orangtua dan kadar Hb.Penelitian ini bertujuan untuk mengetahuifactor-faktor yang mempengaruhi terhadap ketepatan tranfusi anak dengan thalassemia.Penelitian ini menggunakan metode penelitian analitik dengan design crossectional dengan jumlah responden sebanyak 98 orang. Analisis data dalam penelitian ini menggunakan uji chi-square dan regresi logistic. Faktor yang berhubungan dengan ketepatan tranfusi adalah pendidikan orangtua, pendapatan orangtua dan kadar $\mathrm{Hb}$ $(\alpha=0,05)$. Faktor yang paling berpengaruh adalah kadar $\mathrm{Hb}$. Kadar $\mathrm{Hb}$ memungkinkan 83,5 kali berpengaruh terhadap ketepatan tranfusi setelah dikontrol pendidikan dan pendapatan orangtua. Petugas kesehatan sebaiknya selalu memberikan pendidikan kesehtan pada orangtua mengenai kadar $\mathrm{Hb}$ pretransfusi anak $\geq 7 \mathrm{gr} / \%$ Karen aberpengaruh terhadap ketepatan tranfusi.
\end{abstract}

Kata kunci :analisis faktor, ketepatan transfusi, thalasemia

*Poltekkes Kemenkes Banten

\begin{abstract}
Complications in children with beta thalassemia major may occur due to inaccuracies in the transfusion. Accuracy in performing transfusions can be affected by various factors including the age, gender, parental education, parental income and level of $\mathrm{Hb}$. This study aims to determine the factors that affect the accuracy transfusion of children with thalassemia. This study uses cross-sectional analytical study design with a number of respondents as many as 98 people. Analysis of the data in this study using the chi-square test and logistic regression. Factors related to the accuracy of the transfusion is parental education, parental income and $\mathrm{Hb}(\alpha=0.05)$. The most influential factor is the hemoglobin level. Hb allowing 83.5 times affect the accuracy of transfusion after controlled parental education and income. Health workers should always give health education for parental about children's hemoglobin concentration pretransfusi $\geq 7 \mathrm{~g} / \%$ because affected the accuracy transfusion
\end{abstract}

Key words:factor analysis, accuracytransfusions, thalassemia 


\section{Pendahuluan}

Salah satu penyakit kronis yang diderita oleh anak adalah talasemia $\beta$ mayor. Penanganan talasemia bergantung pada ketepatan pemberian tranfusi selain tindakan pemberian obat-obatan yang lain. Ketepatan transfusi ini dilihat dari dua keadaan, yang pertama adalah pasien datang tepat pada waktunya, yang kedua adalah pasien datang dengan keadaan $\mathrm{Hb}$ sama dengan atau lebih dari 7 gr/dl. Angka kejadian talasemia di Indonesia semakin meningkat jumlahnya. dimana angka kelahiran rata-rata $23 \%$ dengan jumlah populasi penduduk sebanyak 240 juta diperkirakan akan lahir 3000 bayi pembawa gen tiap tahunnya (Bulan, 2009).

Pemberian tranfusi pada anak berbeda-beda sesua dengan tingkat keparahan dari umur sel darah merahnya. Ada anak yang diharuskan melakukan tranfusi $2 \mathrm{mgg}$ sekali, 3 mgg atau 4 minggu sekali. Petugas kesehatan atau perawat perlu memperhatikan ketepatan pemberian transfusi, karena semakin tepat tranfusi diberikan maka akan semakin menurunkan angka kejadian komplikasi. Komplikasi yang sangat

membahayakan apabila anak datang tidak tepat waktu atau terlambat akan mengakibatkan kadar $\mathrm{Hb}$ dalam darahnya terlalu rendah yang akan mengakibatkan oksigenasi ke otak akan mengalami hambatan sehingga anak akan mengalami penurunan kesadaran dan kerusakan otak.

Rumah Sakit Umum (RSU) Tangerang merupakan salah satu rumah sakit pemerintah yang berada di Propinsi Banten, memberikan pelayanan khusus pada pasien penderita thalasemia yang memerlukan transfusi darah secara terus menerus. Sampai bulan Desember 2013 jumlah pasien thalasemia sebanyak 357 orang dengan jumlah pasien anak sebanyak 312 anak dan pasien dewasa berjumlah 45 orang, sehingga didapatkan perumusan masalah sebagai berikut"Analisis faktor yang berpengaruh terhadap ketepatan pada anak dengan talasemia $\beta$ mayor yang di rawat di RSU Tangerang"

\section{Metode Penelitian}

Penelitian ini bersifat analitik kuantitatif dengan menggunakan 
pendekatan cross sectional. Populasi penelitian ini berjumlah 312 anak yang menderita thalasemia $\beta$ mayor, dengan jumlah sampel sebanyak 98 orang anak penderita thalasemia $\beta$ mayor, yang diambil secara acak sederhana. Analisis yang digunakan dalam penelitian ini adalah analisis univariat, bivariat, dan multivariat.

\section{Hasil Penelitian}

Hasil penelitianfaktor-faktor yang berhubungan dengan ketepatan tranfusi pada anak thalasemia $\beta$ mayor terhadap ketepatan transfusi di RSU Tangerang. Jumlah responden penelitian sebanyak 98 responden. Analisa univariat untuk mengetahui factor-faktor demografi untuk menjelaskan karakteristik dari masingmasing variabel yang diteliti, analisa bivariat untuk mengetahui masingmasing faktor-faktor demografi yaitu usia, jenis kelamin, pendidikan orangtua, penghasilan orangtua, kadar $\mathrm{Hb}$ dengan ketepatan transfusi. Analisa multivariate akan menjelaskan faktor-faktor demografi dan kadar hb yang paling berpengaruh terhadap ketepatan transfusi.anak thalasemia $\beta$ mayor di RSU Tangerang.

\section{Analisis Univariat}

Variabel independent: data demografi subyek penelitian yaitu usia, jenis kelamin, pendidikan orangtua, penghasilan orangtua. Keadaan yang terkait dengan kondisi penyakit yaitu kadar $\mathrm{Hb}$ dan ketepatan tranfusi.

\section{Tabel 1}

Distribusi Responden Berdasarkan Usia, Jenis Kelamin, Pendidikan Orangtua,

Penghasilan Orangtua dan Kadar Hb di R. Thalasemia RSU Tangerang Thn 2014

\begin{tabular}{|c|c|c|}
\hline Variabel & $\begin{array}{l}\text { Frekuensi } \\
\text { (n) }\end{array}$ & $\begin{array}{c}\text { Prosentase } \\
(\%)\end{array}$ \\
\hline \multicolumn{3}{|l|}{ Usia (tahun) } \\
\hline$>12$ & 29 & 29,6 \\
\hline $0-12$ & 69 & 70,4 \\
\hline \multicolumn{3}{|l|}{ Jenis } \\
\hline Kelamin & 50 & 51 \\
\hline $\begin{array}{l}\text { Perempuan } \\
\text { Laki-laki }\end{array}$ & 48 & 49 \\
\hline \multicolumn{3}{|l|}{ Pendidikan } \\
\hline Orangtua & 63 & 64,3 \\
\hline Tinggi & 35 & 35,7 \\
\hline Rendah & & \\
\hline \multicolumn{3}{|l|}{ Pendapatan } \\
\hline Orangtua & 65 & 66,3 \\
\hline Tinggi & 33 & 33,7 \\
\hline Rendah & & \\
\hline \multicolumn{3}{|l|}{ Kadar Hb } \\
\hline$\geq 7$ & 34 & 34,7 \\
\hline$\leq 6$ & & \\
\hline
\end{tabular}

Tabel 1 Hasil analisis data demografi responden menunjukkan, analisis usia anak sebagian besar 
berusia antara 0-12 tahun adalah 69 orang atau $70,4 \%$. Analisis jenis kelamin memperlihatkan sebagian besar anak berjenis kelamin laki-laki yaitu sebanyak 50 orang anak atau 51\%. Analisis pendidikan orangtua sebagian besar orangtua berpendidikan tinggi yaitu sebanyak 63 orang atau $64,3 \%$. Analisis penghasilan orang tua memperlihatkan, sebagian besar orangtua berpenghasilan diatas UMR yaitu sebanyak 65 orang atau $66,3 \%$. Analisis kadar $\mathrm{Hb}$ memperlihatkan, sebagian besar anak memperlihatkan kadar $\mathrm{Hb}$ pre tranfusi diatas atau sama dengan 7 yaitu sebanyak 64 orang atau $65,3 \%$.

Variabel Dependen pada penelitian ini adalah ketepatan tranfusi pada anak dengan Thalassemia $\beta$ Mayor di RSU Tangerang.

Tabel 2

Distribusi Responden Berdasarkan Ketepatan Transfusi Anak dgn Thalasemia $\beta$ di R. Thalasemia RSU Tangerang

\begin{tabular}{|c|c|c|}
\hline \multicolumn{3}{|c|}{ Thn $2014(\mathrm{n}=98)$} \\
\hline $\begin{array}{l}\text { Usia } \\
\text { (tahun) }\end{array}$ & Frekuensi & Persentase \% \\
\hline Tepat & 67 & 68,4 \\
\hline Tidak & 31 & 31,6 \\
\hline Tepat & & \\
\hline Total & 98 & 100 \\
\hline & 2 & analisi \\
\hline
\end{tabular}

thalasemia $\beta$ mayor di RSU Tangerang memperlihatkan dari responden sebanyak 98, sebagian besar anak memperlihatkan ketepatan tranfusi yaitu sebanyak 67 orang atau $68,4 \%$.

\section{Analisis bivariat}

Dalam penelitian ini analisis bivariate untuk mengetahui gambaran hubungan antara variable independen yaitu factor-faktor yang mempengaruhi ketepatan tranfusi dan variable dependen yaitu ketepatan transfusi, serta memilih variable yang akan dimasukkan dalam analisis multivariate dan masuk pada pemodelan. Adanya hubungan antara factor-faktor yang mempengaruhi ketepatan tranfusi di tunjukkan dengan nilai $\mathrm{p}<0,05$ pada CI (confident Interval) $95 \%$.

Tabel 3

Analisis Korelasi Usia, Jenis Kelamin, Pendidikan Orangtua, Penghasilan Orangtua dan Kadar Hb dengan Ketepatan Transfusi di RSU Tangerang Tahun 2014

\begin{tabular}{cccc}
\hline Variabel & $\mathrm{P}$ & \multicolumn{2}{c}{$95 \% \mathrm{CI}$ EXPB } \\
& value & Lower & Upper \\
\hline Usia & 0,235 & 0,234 & 1,427 \\
Jenis & 0,568 & 0,549 & 2,982 \\
kelamin & & & \\
Pendidikan & 0,000 & 4,262 & 31,027 \\
Orangtua & & & \\
Pendapatan & 0,001 & 4,092 & 29,57 \\
Orangtua & & & \\
Kadar Hb & 0,000 & 26,365 & 577,522 \\
\hline$* \alpha<0,05$ & & &
\end{tabular}


Tabel 3 analisis hubunganan menggunakan rumus chi-square terlihat pada table 3 dengan nilai $\mathrm{p} \leq 0,000$ pada alpha $5 \%$ terdapat pada variable pendidikan orang tua, penghasilan orang tua, dan kadar $\mathrm{Hb}$ anak; yang berarti bahwa ada pengaruh yang signifikan antara pendidikan orang tua, penghasilan orang tua dan kadar $\mathrm{Hb}$ terhadap ketepatan tranfusi. Sedangkan untuk variable usia anak dan jenis kelamin anak memiliki nilai $\mathrm{p}>0,05$, yang berarti tidak ada hubungan yang signifikan antar usia anak dan jenis kelamin anak dengan ketepatan tranfusi.

\section{Analisis Multivariat}

Analisis multivariate ditujukan untuk mengetahui variable independent yang paling berpengaruh terhadap ketepatan tranfusi. Langkah pertama yang dilakukan untuk membuat analisis multivariate membuat pemodelan kandidat. Pemodelan kandidat dilakukan dengan melihat hasil analisis bivariate. Kandidat yang dimasukkan dalam permodelan tersebut adalah dengan nilai signifikansi $>0,25$ variabel independent tidak layak masuk model multivariate.

Hasil analisis mununjukkan nilai $\mathrm{p}$ value jenis kelamin tidak masuk dalam pemodelan multivariate karean nilai $p$ value $>0,25$. Sedangkan Usia $(0,235)$, pendidikan oran tua $(0,000)$, penghasilan oran tua $(0,001)$ dan kadar $\mathrm{Hb}(0,000)$ masuk ke uji multivariate karena nilai $\mathrm{p}$ nya $\leq 0,25$.

Hasil pemodelan akhir analisis multivariabel dapat dilihat pada table 4.

\section{Tabel. 4}

Pemodelan factor yang berhubungan dengan Ketepatan Transfusi anak dengan Thalassemia di RSU Tangerang

\begin{tabular}{ccccccc}
\hline $\begin{array}{c}\text { Variabe } \\
1\end{array}$ & B & $\begin{array}{c}\text { P } \\
\text { vau }\end{array}$ & $\begin{array}{c}\text { Wal } \\
\text { d }\end{array}$ & OR & \multicolumn{2}{c}{$\begin{array}{c}\text { 95\%(forEX } \\
\text { P(B) }\end{array}$} \\
& & e & & & Low & Uppe \\
er & r \\
\hline Usia & - & 0,1 & 2,01 & 0,29 & 0,05 & 1,595 \\
& 1,2 & 55 & 9 & 2 & 3 & \\
& 31 & & & & & \\
Pendidi & 2,1 & 0,0 & 6,23 & 8,20 & 1,57 & 42,75 \\
kan & 04 & 13 & 7 & 1 & 3 & 8 \\
Kadar & 4,4 & 0,0 & 28,7 & 83,5 & 16,5 & 421,6 \\
Hb & 25 & 00 & 08 & 48 & 53 & 81 \\
& & & & & & \\
Constan & - & 0,0 & 16,0 & 0,00 & & \\
& 7,5 & 00 & 47 & 1 & & \\
& 83 & & & & & \\
\hline
\end{tabular}

Tabel 4 menunjukkan bahwa variable yang paling bermakna dilihat dari nilai OR yang paling besar, sehingga pada penelitain ini variable yang paling besar memberikan pengaruhnya adalah kadar $\mathrm{Hb}$. Hasil analisis OR dari variable kadar $\mathrm{Hb}$ adalah 83,5 kali 
memungkinkan ketepatan tranfusi setelah diontrol oleh usia dan pendididkan orangtua.

\section{Pembahasan}

\section{Jenis kelamin}

Jenis kelamin pada penelitian ini paling banyak berjenis kelamin perempuan yaitu sebanyak 51\%. Pada penelitian tidak ada perbedaan signifikan antara anak penderita thalasemia yang perempuan dan lakilaki. Pada penelitian ini jenis kelamin tidak mempengaruhi ketepatan transfusi $\quad(p=0,568, \alpha<0,005)$. Penelitian ini sejalan dengan penelitian sebelumnya, yaitu Bulan (2009) pada karakteristik demografi jenis kelamin, responden anak dengan thalasemia yang berjenis kelamin perempuan lebih banyak daripada lakilaki yaitu 54\%. Pada penelitian yang dilakukan Thavorncharoenshap et al (2010) bahwa jenis kelamin pada anak thalasemia tidak berbeda antara lakilaki dan perempuan, hal ini terjadi sesuai dengan hukum mendel bahwa gen thalasemia beta mayor diturunkan secara autosomal resesif tidak tergantung jenis kelamin sehingga anak dari pembawa sifat mempunyai anak lahir normal 25\%, sebagai pembawa sifat $50 \%$ dan kemungkinan penderita $25 \%$.

\section{Usia}

Usia anak dalam penelitian ini adalah sebagian besar usia nak antara 0-12 tahun yaitu 70,4\%. Penyakit thalassemia adalah penyakit bawaan, sebagian besar anak yang membawa gen thalassemia akan mulai menunjukkan gejala dibawah usia 2 tahun, sehingga responden dalam penelitian ini sebagian besar adalah anak-anak di bawah usia 12 tahun. Menurut Fan,(2008) meningkatnya pertumbuhan dan perkembangan anak, kemampuan anak dalam perawatan diri semakin meningkat. Pada anak usia sekolah anak sudah mampu memahami kondisi sakit yang diderita dan mampu berpartisipasi dalam pemahaman status kesehatannya. Pada tahap usia sekolah anak berkurang ketergantungannya dengan orang lain dan mulai bertanggungjawab untuk terlibat dalam upaya perawatan serta upaya mempertahankan status kesehatannya. Usia anak dalam penelitian ini tidak berpengaruh terhadap ketepatan 
trasfusi. Ketepatan tranfusi adalah bagian dari sikap kemandirian yang seharusnya dimiliki oleh anak yang lebih besar, karena terkait dengan regimen pengobatan yang utama pada anak yang menderita thalassemia. Berdasarkan data tersebut peneliti berasumsi bahwa usia tidak mempengaruhi ketepatan tranfusi karena pada anak thalassemia meskipun usianya lebih besar tetapi keadaan anak dengan penyakit thalasemia berpengaruh terhadap kemandiriannya dan orangtua biasanya akan memperlakukan anak tersebut lebih khusus dibandingkan anak normal lainnya. Hal tersebut akan mempengaruhi tingkat kemandirian anak dengan penyakit kronis terutama tersebut. Anak dengan kondisi $\mathrm{Hb}$ yang rendah biasanya akan disertai dengan gejala pucat, lemah dan sesak nafas, kondisi ini akan mempengaruhi anak tergantung dengan orang dewasa di sekitarnya sehingga akan mempengaruhi ketepatan transfusi yang dilakukan. Hal ini sesuai dengan Boyse (2008) dalam mengelola keadaan sakit anak, dapat menganggu kebutuhan anak untuk belajar berjalan atau anak yang lebih besar untuk mencapai tingkat kemandirian yang lebih tinggi dan menghambat kesadaran akan control diri serta otonominya. Anak usia sekolah dan remaja juga dapat merasa khawatir karena pembatasan kebutuhan pengobatan dan disabilitas yang terkait nyata yang berhubungan dengan kondisi mereka dapat membuat mereka berbeda dari teman sebayanya. Maka disimpulkan tidak ada pengaruh atau hubungan antara usia dengan ketepatan tranfusi ( $\mathrm{p}=0,235 \alpha<0,005)$.

\section{Pendidikan Orangtua}

Hasil penelitan pendidikan orangtua dengan responden sebanyak 98 orang menunjukkan orangtua yang berpendidikan tinggi sebanyak $64,3 \%$. Pendidikan orangtua berpengaruh secara signifikan terhadap ketepatan transfusi ( $p=0,00 \alpha<0,005)$. Penelitian ini sejalan dengan penelitian yang dilakukan oleh Bulan (2009), bahwa pendidikan orangtua berpengaruh terhadap ketepatan tranfusi. Bulan menyatakan bahwa hal ini dimungkinkan karena tingkat pendidikan mencerminkan tingkat pengetahuan terhadap penyakit dan 
kontribusinya terhadap perjalanan penyakit. Peneliti berasumsi bahwa tingkat pendidikan orangtua yang tinggi akan mempengaruhi terhadap pengetahuanya terhadap tindakan yang harus dilakukan agar anak dengan thalassemia dapat bertahan hidup dan mencegah komplikasi yang terjadi. Pengobatan dan penanganan utama pada anak dengan thalassemia adalah dengan cara melakukan tranfusi sesuuai dengan anjuran. Hal tersebut menjadikan orangtua akan memenuhi setiap anjuran yang berikan sehingga akan melakukan tranfusi pada anaknya secara tepat.

\section{Pendapatan Orangtua}

Pendapatan orangtua dalam penelitian ini sebagian besar berpenghasilan tinggi sekitar $66,3 \%$. Ada hubungan yang signifikan antara pendapatan orangtua dengan ketepatan transfusi $\quad((\mathrm{p}=0,001 \quad \alpha<0,005)$. Penelitian ini sejalan dengan penelitian yang lain yaitu Mariani (2011), Bulan (2009) dan Clarke et al (2009). Pendapatan orangtua yang tinggi akan dapat memfasilitasi anak untuk mendapatkan pengobatan yang baik, meskipun di RSU Tangerang pasien anak dengan tahalsemia dibebankan kepada pemerintah karena adanya program BPJS, tetapi kebutuhan keluarga tetap meningkat terutama untuk biaya operasional yang tidak dijamin pemerintah seperti transportasi dan akomodasi.

\section{Kadar Hb}

Kadar $\mathrm{Hb}$ pretransfusi anak dengan thalasemia, sebagian besar datang dengan kadar $\mathrm{Hb} \geq 7$. Hubungan kadar $\mathrm{Hb}$ ini signifikan mepengaruhi ketepatan transfusi $(\mathrm{p}=0,000 \quad \alpha<0,005)$. Kadar $\mathrm{Hb}$ anak dengan thalassemia harus dipertahankan diatas 7gr\%, karena apabila kadar $\mathrm{Hb}$ rendah akan mempengaruhi komplikasi yang akan terjadi. Pada penelitian ini ketepatan dilihat dari kadar $\mathrm{Hb}$ yang tidak boleh kurang dari 7 dan daatang sesuai dengan waktu yang telah ditentukan. Semakin baik kadar $\mathrm{Hb}$ pretransfusinya maka akan semakain baik ketepatan tranfusi yang dilakukan.

\section{Analisis hubungan faktor-faktor yang berhubungan dengan ketepatan

$\begin{array}{rrr} & \text { Berdasarkan hasil analisis } \\ \text { dapat disimpulkan bahwa bahwa }\end{array}$


variable yang paling bermakna pada penelitain ini variable yang paling besar memberikan pengaruhnya adalah kadar $\mathrm{Hb}$. Hasil analisis OR dari variable kadar $\mathrm{Hb}$ adalah 83,5 kali memungkinkan ketepatan tranfusi setelah dikontrol oleh usia dan pendididkan orangtua.

Kadar $\mathrm{Hb}$ pretransfusi sangat mempengaruhi ketepatan transfusi. Pada penelitian ini ketepatan transfusi dilihat dari dua faktor, yang pertama pasien harus datang tepat waktu sesuai dengan jadwal yang telah ditentukan, kedua adalah pasien datang dengan kadar $\mathrm{Hb}$ pretransfusi yang lebih atau sama dengan 7. Bila kedua hal ini tidak dapat dipenuhi maka pasien dikatakan tidak tepat dalam melakukan transfusi. Penelitian ini sejalan dengan beberapa penelitian sebelumnya diantaranya Bulan (2009) yang menjelaskan bahwa rerata kadar $\mathrm{Hb}$ pretransfusi responden sebesar 7,8 gr\%, dari hasil uji statistik didapatkan hubungan yang bermakna antara rerata nilai kualitas hidup dengan kadar $\mathrm{Hb}$ pretransfusi. Rendahnya kadar $\mathrm{Hb}$ pretransfusi mengakibatkan penderita mengalami keterlambatan pertumbuhan, terjadi perubahan pada wajah dan pembesaran limpa (Ghorashi, 2007). Thavorncharoensap et al (2010) menjelaskan bahwa kadar $\mathrm{Hb}$ pretransfusi yang rendah berhubungan dengan adanya beberapa gejala seperrti kelelahan, kelemahan umum, dan penurunan status mental dan mempengaruhi kualitas hidup masing-masing domain. Kadar $\mathrm{Hb}$ pretransfusi sebaiknya dimonitor secara rutin untuk mempertahankan kadar Hb pada 9-10,5 gr.

\section{Simpulan}

Berdasarkan hasil penelitian factorfaktor yang mempengaruhi ketepatan tranfusi anak dengan thalassemia $\beta$ Mayor di RSU Tangerang, disimpulkan bahwa Usia anak dalam penelitian ini sebagian besar berusia diantara 0-12 tahun yaitu sebanyak $70,4 \%$. Usia tidak berpengaruh terhadap ketepatan tranfusi anak dengan thalassemia beta mayor $(p=0,235 \alpha=0,05)$.Jenis kelamin anak dalam penelitian ini adalah perempuan yaitu sebanyak $51 \%$. Jenis kelamin tidak berpengaruhterhadap ketepatan tranfusi ( $p=0,508 \alpha=0,05)$. Pendidikan orangtua dengan anak thalassemia sebagian besar berpendidikan tinggi 
yaitu sebanyak 64,3\%. Pendidikan orangtua berpengaruh terhadap ketepatan tranfusi $(p=0,000 \quad \alpha=0,05)$. Pendapatan orangtua dengan anak thalassemia sebagian besar mempunyai pendapatan tinggi yaitu sebanyak $66,3 \%$. Pendapatan orangtua berpenagruh terhadap ketepatan tranfusi. ( $p=0,001 \alpha=0,05)$. Kadar $\mathrm{Hb}$ anak sebelum tranfusi sebagian besar mempunyai kadar $\mathrm{Hb} \geq 7$ gr/\% yaitu sebanyak 65,3\%. Kadar $\mathrm{Hb}$ berpengaruh terhadap ketepatan tranfusi ( $p=0,00 \alpha=0,05)$. Faktor yang paling berpengaruh terhadap ketepatan tranfusi adalah kadar $\mathrm{Hb}$. Kadar $\mathrm{Hb}$ memungkinkan 83,5 kali ketepatan tranfusi setelah dikontrol oleh usia dan pendidikan.

\section{Daftar Pustaka}

Arikunto, S. 2006. Prosedur Penelitian Suatu Pendekatan Praktik. Edisi Revisi 6. Jakarta PT. Rineka Cipta.

Bulan, S. 2009. Faktor-faktor yang berhubungan dengan kualitas hidup anak talasemia beta mayor.

eprints.undip.ac.id/24717/1/San dra_Bulan.pdf , diunduh pada tanggal 18 Pebruari 2013

Fan, L (2008). Self care behavior of school age children with heart desease. Pediatric Nursing.
Hockenberry, M.J. \& Wilson, D. (2009). Wong Essensials of Pediatric Nursing. Philadelphia: Mosby Elsevier.

Johari S, Karimi M. 2008. Socioeconomic and cultural factors affecting family planning among families of thalassemic children in Southern Iran. http://yith.ir/download/ejtemaei/ num10.pdf, diakses tanggal 18 Februari 2013

Lee, Y.L, D.T. \& Tsai, S.F. (2008).

Disease Knowledge and treatment adherence among patient with thalasemia major and their mothers in Taiwan, Journal of clinical, 18, 529-538

Mariani, D.T (2011). Analisi factor yang mempengaruhi kulaitas hidup anak thalassemia Beta Mayor di RSU Kota Tasikmalaya dan Ciamis http://www.google.co.id/digital 20280656-T Dini Mariani.pdf, diunduh 12 Pebruari 2014

Nugroho, D dkk (tahun).Faktor-faktor yang berhubungan dengan kualitas hidup pasien thalassemia Mayor di Pusat Thalasemia Departemen Ilmu Kesehatan Anak RSCM.http://saripediatri.idai.or. id/pdfile/11-2-2.pdf, diunduh 10 pebruari 2014

Sugiyono.Metode

Penelitian Kuantitatif dan Kualitatif Dan R \& D. cetakan ke 7. CV Alfabeta. Bandung. 2009.

Wahidiyat PAW. Problem and management of thalassemia in Jakarta. Department of child health FKUI. PIT Yogyakarta. 2007. 
